\title{
EDITORIAL EJJL
}

A EJJL cresceu e se qualificou muito nesses últimos 8 anos. Tornou-se um importante cartão de apresentação do trabalho que fazemos no PPGD da Unoesc. Preocupados com esse movimento, os Editores vêm planejando mudanças e trabalhando, desde 2018, em soluções para melhorar seu processo Editorial. Agora estamos prontos para anunciá-las e implementá-las.

Iniciamos esse movimento pela atualização tecnológica. Com imprescindível ajuda técnica da equipe da Editora Unoesc, adotamos uma nova versão do sistema OJS. Muitos de nossos autores e avaliadores notaram que essa migração foi difícil. Levou mais tempo do que esperávamos e apresentou mais percalços técnicos do que gostaríamos. Devemos sinceros pedidos de desculpas por isso. Todavia, a versão mais recente do sistema está agora devidamente implantada. É mais intuitiva e oferece melhores recursos para o trabalho de gestão. Todos ganhamos.

Depois, iniciamos um redesenho de equipe, papéis e funções da Comissão Editorial.

Quanto às funções e papéis da equipe, a principal inovação diz respeito ao ensino da editoração. A partir deste segundo semestre de 2019, a EJJL passou a se integrar com o plano de formação do PPGD, pois os Editores passaram a ensinar editoração a estudantes de mestrado e doutorado.

A experiência e resultados acumulados nos últimos 8 anos são bastante boas para ousar a realizar essa integração entre ensino, pesquisa e editoração científica. Criamos, assim, o Laboratório de Práticas Editoriais da EJJL no PPGD da Unoesc. Estudantes do doutorado e do mestrado agora atuam como editores assistentes supervisionados por três editores-adjuntos e pelo Editor-Chefe da Comissão Editorial. Agora, nossos mestrandos e doutorandos participam de todos os momentos do planejamento, gestão e tomada de decisões, num rico ambiente de discussões e aprendizado técnico da etapa de publicação do fazer científico. Os primeiros resultados já revelam o acerto da decisão.

Quanto à Equipe Editorial e suas atribuições, importante mudança ocorreu com a alternância na função de Editor-Chefe. Desde que assumiu essa função, em 2012, o Prof. Carlos Luiz Strapazzon veio liderando a Revista até este ano de 2019, quando pediu afastamento da função de chefia. Contudo, permanece conosco como Editor-Adjunto e membro do Conselho Editorial. A partir deste número, o novo Editor-Chefe é o Prof. Marco Aurélio Rodrigues da Cunha e Cruz, que está na Comissão Editorial da EJJL desde 2012, sempre como Editor-Adjunto e que participou ativamente de todos os momentos e transformações da Revista. A EJJL está pronta para aprimorar seu processo de alternância na função de Editor-Chefe.

Ainda com relação à equipe editorial, a EJJL também passou a ter uma Secretaria com novas funções. Além das funções normais de gestão de documentos, a Secretaria recebeu qualificação técnica para operar o OJS na versão atual e auxiliar na gestão e capacitação de mestrandos, doutorandos e novos editores. 
Quanto aos editores-adjuntos, serão também supervisores do aprendizado de editoração científica, no contexto do Laboratório de Práticas Editoriais. Para isso, além da participação do Prof. Carlos Luiz Strapazzon e do Prof. Wilson Steinmetz, a EJJL ganhou a participação da Profa. Regina Stela Correa Vieira e do Dr. Paulo Junior Trindade dos Santos, depois da saída dos Prof. Robison Tramontina (que assumiu a coordenação do PPGD) e do Prof. Matheus Felipe de Castro (que pediu afastamento temporário).

Quanto ao foco e escopo, nada mudou. A EJJL quer cumprir sua missão de ser um importante veículo de difusão de resultados de pesquisa científica. Pesquisa importante, com significado relevante para o desenvolvimento da teoria dos direitos fundamentais, das políticas públicas e das práticas profissionais de todas as carreiras jurídicas. A EJJL, assim, ajuda a realizar o impacto científico do PPGD, ao mesmo tempo em que colabora com a formação de uma nova geração de autores e de editores de ciência baseada em evidências.

A cultura da ciência não impede a EJJL de publicar trabalhos sem essas características, como entrevistas, análises de jurisprudência. Todavia, trabalhos outros sempre devem representar um conhecimento importante e aderente à missão da Revista.

Em tempos de dúvidas, preconceitos - e até desprezo pela função e o papel do saber científico -, a EJJL não hesita em aplicar ao seu fazer o que há de melhor nas práticas das ciências de nosso tempo, nem hesitará em dar a máxima visibilidade para a boa produção científica sobre direitos fundamentais.

Boa leitura.

Editorial assinado por: Carlos Luiz Strapazzon (Editor-Chefe, 2012-2019/1). Marco Aurélio Rodrigues da Cunha e Cruz (Editor-Chefe 2019/2-2021). 